GASTROESOPHAGEAL REFLUX DISEASE

(GERD). A condition in which gastric contents are refluxed into the oesophagus, characterized by the symptom of heartburn.

GASTROENTERITIS Acute gastrointestinal infection caused by bacterial or viral agents. It is characterized by nausea, vomiting and diarrhoea.

${ }^{*}$ Division of Gastroenterology,

Vanderbilt University School of Medicine,

C-2104 Medical Center

North, Nashville,

Tennessee 37232-2279, USA. ${ }^{\ddagger}$ Departments of Medicine and Microbiology, New York University School of Medicine and New York Harbor Veterans Affairs Medical Center, New York, New York 10016, USA.

Correspondence to R.M.P. e-mail:

richard.peek@mcmail.vande rbilt.edu DOI: $10.1038 / \mathrm{nrc} 703$

\title{
HELICOBACTER PYLORI AND GASTROINTESTINAL TRACT ADENOCARCINOMAS
}

\section{Richard M. Peek Jr ${ }^{*}$ and Martin J. Blaser ${ }^{*}$}

Although gastric adenocarcinoma is associated with the presence of Helicobacter pylori in the stomach, only a small fraction of colonized individuals develop this common malignancy. $\mathrm{H}$. pylori strain and host genotypes probably influence the risk of carcinogenesis by differentially affecting host inflammatory responses and epithelial-cell physiology. Understanding the host-microbial interactions that lead to neoplasia will improve cancer-targeted therapeutics and diagnostics, and provide mechanistic insights into other malignancies that arise within the context of microbially initiated inflammatory states.

Gastric adenocarcinoma is the second leading cause of cancer-related death in the world ${ }^{1}$. Epidemiological and interventional studies in humans, as well as experiments in rodents, have associated Helicobacter pylori - a member of a large family of related bacteria that colonize the mammalian stomach - with peptic ulcers, nonHodgkin's lymphoma of the stomach, gastric atrophy and distal gastric adenocarcinoma ${ }^{2-10}$. However, only a small percentage (probably less than 3\%) of individuals that carry H. pylori ever develop neoplasias related to its presence, indicating that other factors are involved. Such observations, along with recent evidence that certain $H$. pylori strains might reduce the risk of GASTROESOPHAGEAL REFLUX DISEASE (GERD) and its complications (for example, oesophageal adenocarcinoma) ${ }^{11,12}$, underscore the importance of understanding the biological interactions of these organisms with their host.

\section{H. pylori epidemiology}

$H$. pylori is present in the stomachs of at least half of the world's population. It is usually acquired in childhood, and when left untreated generally persists for the host's lifetime ${ }^{13}$. Once established, H. pylori has no significant bacterial competitors and - except for transient bacteria - the stomach is essentially a monoculture of $H$. pylori. Although people in all geographical zones carry the bacteria, the prevalence of
H. pylori is higher in developing countries than in developed countries ${ }^{13,14}$. In the United States, $H$. pylori is present in $10-15 \%$ of children who are less than 12 years old, compared with $50-60 \%$ of people greater than 60 years old ${ }^{13-15}$. The rate of acquisition of new $H$. pylori infections among adults in developed countries is less than $1 \%$ per year ${ }^{14}$, and most American carriers probably acquired $H$. pylori during childhood. Over the past half-century, however, progressively fewer children have been shown to carry H. pylori - this decrease has been accelerated by the widespread use of antibiotics. Risk factors for H. pylori acquisition include low socioeconomic status, household crowding, country of origin and ethnicity $^{13,16}$. Colonization is related to intrafamilial clustering, but not to the presence of non-primate reservoirs, indicating that transmission of $H$. pylori from person to person occurs ${ }^{13}$. Induction of regurgitation and catharsis increased the chance of obtaining a positive $H$. pylori culture from vomitus and diarrhoeal specimens ${ }^{17}$, which indicates that $H$. pylori transmission might be associated with childhood episodes of GASTROENTERITIS.

\section{$H$. pylori and gastric cancer}

Two histologically distinct variants of gastric adenocarcinoma have been described, each having 


\section{Summary}

- Gastric adenocarcinoma is the second leading cause of cancer-related deaths in the world, and has been associated with the presence of Helicobacter pylori in the stomach.

- Gastric cancer involves a transition from normal mucosa to gastritis, which then leads eventually to adenocarcinoma. The ability of $H$. pylori to induce superficial gastritis indicates that it is involved in the initiation and promotion of gastric neoplasia. Many clinical and animal studies support this idea.

- H. pylori populations are extremely diverse, due to point mutations, substitutions, insertions and/or deletions in their genomes. Cancer risk is believed to be related to H. pylori strain differences.

- There are also a number of human polymorphisms associated with gastric cancer. Most of these occur within immune-response genes.

- H. pylori have a number of direct effects on host epithelial tissues that could affect tumorigenesis, including induction of proliferation, the inflammatory response and apoptosis.

- So, host and pathogen are likely to be linked in a dynamic equilibrium, in which the host responses to bacterial colonization affect the growth of certain bacterial strains, and strain phenotype affects the nature of the host response.

- Remarkably, the presence of $H$. pylori reduces the risk of developing other types of cancer, such as oesophageal adenocarcinoma. The same biological effects of $H$. pylori that predispose people to gastric cancer are likely to protect them from oesophageal cancer.
GASTRITIS

Inflammation within the gastric mucosa. Gastritis induced by H. pylori involves

polymorphonuclear cells, lymphocytes ( $\mathrm{T}$ and $\mathrm{B}$ cells), macrophages and plasma cells.

ATROPHIC GASTRITIS An intermediate histological step in the progression to intestinaltype gastric adenocarcinoma characterized by variable gland loss and encroachment of inflammatory cells into the glandular zones.

INTESTINAL METAPLASIA A premalignant histological lesion in the progression to intestinal-type gastric adenocarcinoma, in which normal gastric mucosa is replaced by intestinal-type epithelial cells.

DYSPLASIA

Neoplasia that involves lining epithelial cells that have not breached the basement membrane (which separates epithelial cells from the underlying lamina propria), and the capacity to metastasize is therefore absent.

ADENOCARCINOMA Fully transformed malignant tissue arising from glandular epithelium. different epidemiological and pathophysiological features. Intestinal-type gastric adenocarcinoma usually occurs at a late age, predominates in men and progresses through a relatively well-defined series of histological steps ${ }^{18}$. Diffuse-type gastric adenocarcinoma more commonly affects younger people, affects men and women equally and consists of individually infiltrating neoplastic cells that do not form glandular structures and are not associated with intestinal metaplasia $^{18}$. Although $H$. pylori significantly increases the risk of developing both subtypes of gastric adenocarcinoma, the mechanisms underpinning the development of intestinal-type cancer are more well-characterized; therefore, the remainder of this review will focus predominantly on the relationships between $H$. pylori and intestinal-type gastric adenocarcinoma.

The chain of events that occurs during development of intestinal-type gastric cancer involves a transition from normal mucosa to chronic superficial GASTRITIS, which then leads to ATROPHIC GASTRITIS and INTESTINAL METAPLASIA, and finally to DYSPLASIA and ADENOCARCINOMA ${ }^{1}$ (FIG. 1). The as the extent of atrophic gastritis and intestinal metaplasia increases, and patients with severe multifocal atrophic gastritis have over a 90 -fold greater risk of developing adenocarcinoma than those with normal mucosa ${ }^{18}$. In contrast to the apparent 'orderly' sequence of genetic mutations that accumulate during colorectal carcinogenesis, no mutational events are consistently associated with intermediate steps in the progression to intestinal-type gastric adenocarcinoma (FIG. 1) ${ }^{19-21}$. The ability of $H$. pylori to induce superficial gastritis ${ }^{22}$, however, indicates that this organism - or the host inflammatory response to it - could be important in the initiation and promotion of gastric neoplasia.

Epidemiological studies indicate that H. pylori colonization increases the risk of developing distal (noncardia) gastric cancer (FIG. 2). The progressive decline in $H$. pylori acquisition during the last century by people living in developed countries has been mirrored by a decreasing incidence of these gastric cancers ${ }^{23,24}$. Several case-controlled studies have shown that $H$. pylori seropositivity is associated with a significantly increased risk of gastric cancer (2.1-16.7-fold greater than in seronegative persons $)^{5-10,25-30}$. In developed countries, $H$. pylori probably increases the risk of developing gastric cancer by sixfold ${ }^{31}$. The actual risk of gastric cancer that is attributable to H. pylori might be even higher, because $H$. pylori colonization diminishes in the presence of premalignant lesions, such as gastric atrophy or intestinal metaplasia, making it difficult to detect in all patients. Importantly, prospective studies have shown that the longer the time interval between $H$. pylori detection and gastric cancer diagnosis, the higher the risk of developing cancer $^{31}$.

Results from several studies, reporting that antimicrobial treatment alters gastric carcinogenesis, also implicate $H$. pylor $i$ in the progression to neoplasia. A randomized controlled chemoprevention trial showed that antimicrobial therapy directed against H. pylori increased the regression rate of gastric atrophy and intestinal metaplasia, compared with patients receiving placebo ${ }^{32}$. In Japanese patients with early gastric cancer, therapy to eliminate $H$. pylori resulted in a significantly lower rate of gastric cancer risk of developing gastric cancer increases exponentially

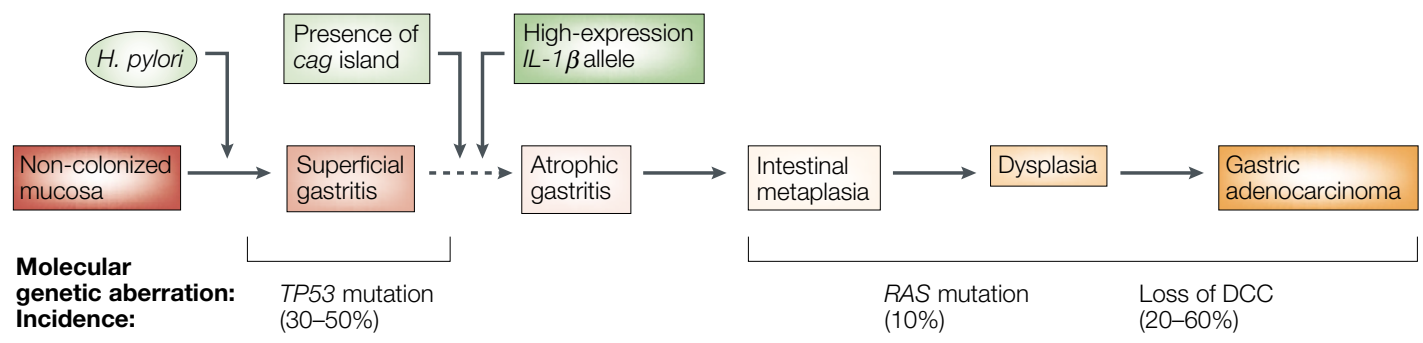

Figure 1 | Progression to intestinal-type gastric adenocarcinoma. Helicobacter pylori colonization usually occurs during childhood and, over a period of days to weeks, leads to superficial gastritis. The presence of host TP53 mutations, host polymorphisms that promote high expression levels of the cytokine interleukin (IL)-1 $\beta$, and the cag island within infecting $H$. pylori isolates all contribute to the development of atrophic gastritis, intestinal metaplasia, dysplasia and, eventually, gastric adenocarcinoma over the course of many years. Additional mutations in oncogenes that encode RAS or deleted in colorectal cancer (DCC) might also contribute to intestinal-type gastric carcinogenesis. 

Transfer of DNA from one bacterial species to another.
HORIZONTALLY ACQUIRED

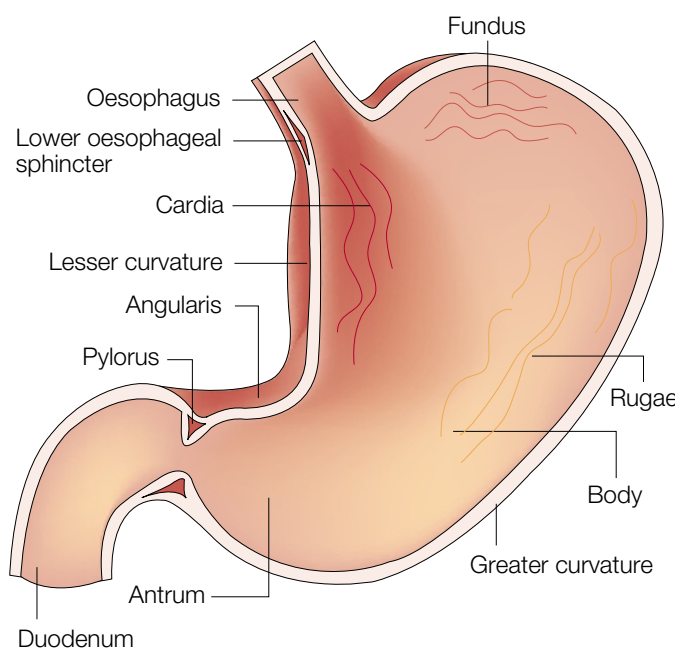

Figure 2 | Gastric anatomy. Anatomical arrangement of the distal oesophagus, stomach and proximal duodenum. Helicobacter pylori-induced inflammation can occur at any site within the stomach. However, most intestinal-type and diffuse gastric adenocarcinomas associated with $\mathrm{H}$. pylori occur in the gastric antrum, body, or (less likely) fundus. Oesophageal adenocarcinomas - which are a complication of gastroesophageal reflux disease and Barrett's oesophagus, and are inversely related to the presence of $H$. pylori - occur in the distal oesophagus, just above and/or involving the lower oesophageal sphincter.

recurrence and reduced progression of atrophic gastritis ${ }^{33}$. In a recent long-term prospective study, $H$. pylori eradication prevented, or at least delayed, the development of gastric adenocarcinoma during a mean follow-up period of 4.8 years ${ }^{34}$.

$H$. pylori also induces gastric cancer in rodent models. Following experimental challenge with H. pylori, Mongolian gerbils consistently develop pan-gastritis ${ }^{35}$, which leads, over the course of 1-2 years, to gastric atrophy, intestinal metaplasia and intestinal-type gastric adenocarcinoma in up to one-third of animals ${ }^{36,37}$. The pattern of gastric cancer development in these

\begin{tabular}{|c|c|c|}
\hline \multicolumn{3}{|c|}{ Genetic locus } \\
\hline cag island & vacA & babA2 \\
\hline \multicolumn{3}{|l|}{ Conservation between strains } \\
\hline $\begin{array}{l}\text { 60-70\% Western strains } \\
\text { 95-100\% Asian strains }\end{array}$ & $\begin{array}{l}\text { Always present, } \\
\text { alleles vary }\end{array}$ & $\sim 85 \%$ \\
\hline \multicolumn{3}{|l|}{ Function } \\
\hline $\begin{array}{l}\text { Forms scaffold apparatus } \\
\text { that allows bacterial protein(s) } \\
\text { to enter host epithelial cells }\end{array}$ & $?$ & $\begin{array}{l}\text { Bacterial adhesion } \\
\text { to cell surface }\end{array}$ \\
\hline \multicolumn{3}{|c|}{ Epidemiological disease association } \\
\hline $\begin{array}{l}\text { Peptic ulcer disease, } \\
\text { gastric cancer }\end{array}$ & $\begin{array}{l}\text { Peptic ulcer disease, } \\
\text { gastric cancer }\end{array}$ & $\begin{array}{l}\text { Peptic ulcer disease, } \\
\text { gastric cancer }\end{array}$ \\
\hline \multicolumn{3}{|c|}{ Genotype associated with disease } \\
\hline $\operatorname{cag}^{+}$ & vacAs1m1 & babA2+ \\
\hline
\end{tabular}

animals parallels that of humans (FIG. 1), making this a good model of gastric carcinogenesis. Malignancy can be induced by $H$. pylori colonization alone, without the exogenous administration of co-carcinogens. Accordingly, the World Health Organization has classified $H$. pylori as a class I carcinogen of gastric cancer ${ }^{38}$.

\section{Strain variation and disease risk}

If $H$. pylori is the strongest identified risk factor for the development of distal gastric cancer, why do most carriers never develop this malignancy? Cancer risk is believed to be related to $H$. pylori strain differences, inflammatory responses governed by host genetics, and specific interactions between host and microbial determinants. H. pylori populations are extremely diverse $\mathrm{e}^{39}$, owing to point mutations, substitutions, insertions and/or deletions in their genomes ${ }^{40}$. A single host can carry several $H$. pylori strains, and isolates within an individual can change over time as endogenous mutations, chromosomal rearrangements or recombination between strains occurs ${ }^{40,41}$. Although this extraordinary diversity has made it difficult to search for bacterial factors that are associated with malignancy, several genetic loci have been identified, including the cag pathogenicity island, the vacA gene and the $b a b A 2$ gene (TABLE 1). These markers seem to be interdependent, and are not absolutes, but reflect degree of risk ${ }^{42,43}$.

The cag island. The most important distinguishing factor of $H$. pylori strains is presence of the cag island, a HORIZONTALLY ACQUIRED locus of approximately $40 \mathrm{~kb}$ that contains 31 genes $^{44,45}$. Several cag island genes have homology to genes that encode type IV secretion system proteins, which export proteins from bacterial cells. The terminal gene in the island, cagA, is commonly used as a marker for the entire cag locus. Following H. pylori adherence to epithelial cells, the secretion system translocates the CagA protein from $H$. pylori into the epithelial cell, where it undergoes tyrosine phosphorylation - a process that is associated with dephosphorylation of host-cell proteins $s^{46-48}$ and host-cell morphological changes ${ }^{49}$. The phosphorylated form of CagA might therefore function as a phosphatase that regulates organization of the actin cytoskeleton.

Compared with $c a g A^{-}$strains, $H$. pylori $c a g A^{+}$strains significantly increase the risk of developing severe gastritis, atrophic gastritis, peptic ulcer disease and distal gastric cancer ${ }^{50-56}$ (FIG. 1). In vitro studies have shown that several genes within the cag island ( $\operatorname{cag} E$ ( $p i c B), c a g G$, cagH, cagI, cagL, cagM, but not cagA) are required for release of pro-inflammatory cytokines induced by $H$. pylori, such as interleukin (IL)-8, from gastric epithelial cells $^{57-59}$. Inactivation of these same genes also results in decreased activation of the nuclear factor- $\kappa \mathrm{B}(\mathrm{NF}-\kappa \mathrm{B})$ and mitogen-activated protein kinase (MAPK) signaltransduction cascades, which regulate pro-inflammatory cytokine production ${ }^{59-63}$. These in vitro observations mirror in vivo events, as $\mathrm{Cag}^{+}$strains are associated with increased mucosal expression of IL-8 and inflammation in human gastric tissue ${ }^{52,64}$. Furthermore, loss of $c a g E$ or the entire cag locus profoundly attenuates the severity of 


\begin{tabular}{|c|c|c|c|c|}
\hline Gene & $\begin{array}{l}\text { Function of gene } \\
\text { product }\end{array}$ & $\begin{array}{l}\text { Polymorphism associated } \\
\text { with enhanced risk }\end{array}$ & $\begin{array}{l}\text { Relative risk of } \\
\text { gastric cancer; } \\
\text { odds ratio ( } 95 \% \\
\text { confidence intervals) }\end{array}$ & Comment \\
\hline$I L-1 \beta$ & $\begin{array}{l}\text { Induces expression of } \\
\text { inflammatory cytokines; } \\
\text { potently inhibits acid } \\
\text { secretion from parietal } \\
\text { cells }\end{array}$ & $\begin{array}{l}-31 \mathrm{C} / \mathrm{C} \\
-511 \mathrm{~T} / \mathrm{T}\end{array}$ & $\begin{array}{l}2.5(1.6-3.8) \\
2.6(1.7-3.9)\end{array}$ & $\begin{array}{l}\text { Cancer risk increased } \\
\text { compared with } \\
\text { individuals positive for } \\
\text { H. pylori with 'low- } \\
\text { expression' alleles } 87 \text {; } \\
\text { also increases risk for } \\
\text { atrophic gastritis }\end{array}$ \\
\hline IL-1R $\beta$ & Receptor for IL-1 $\beta$ & $\begin{array}{l}\text { Penta-allelic 86-bp tandem } \\
\text { repeat in intron } 2\end{array}$ & $2.9(1.9-4.4)$ & REF. 87 \\
\hline$T N F-\alpha$ & $\begin{array}{l}\text { Activates intracellular } \\
\text { signalling pathways } \\
\text { related to inflammation } \\
\text { and apoptosis; inhibits } \\
\text { acid secretion from } \\
\text { parietal cells }\end{array}$ & $-308 \mathrm{~A} / \mathrm{A}$ & $1.9(1.2-2.8)$ & REF. 91 \\
\hline IL-10 & $\begin{array}{l}\text { Inhibits production of pro- } \\
\text { inflammatory cytokines }\end{array}$ & $\begin{array}{l}\text {-592 ATAVATA } \\
\text {-819 ATAVATA } \\
\text {-1082 ATAVATA }\end{array}$ & $3.4^{*}(1.4-8.1)$ & $\begin{array}{l}\text { 'Low-expression' } \\
\text { polymorphism } \\
\text { associated with } \\
\text { increased cancer } \\
\text { risk }^{93}\end{array}$ \\
\hline
\end{tabular}

gastritis and development of atrophy in Mongolian gerbils infected with H. pylori ${ }^{65,66}$.

The vacA gene. Another gene that is associated with carcinogenesis induced by $H$. pylori is vacA. vacA encodes a secreted protein that induces vacuole formation in eukaryotic cells and stimulates epithelial-cell apoptosis $^{67-70}$. Approximately $50 \%$ of $H$. pylori strains express the VacA protein ${ }^{71}$, and expression is correlated with expression of $c a g A^{72,73}$. However, vacA and cagA map to separate loci on the $H$. pylori chromosome, and an inactivating cagA mutation does not affect VacA production $^{74}$. H. pylori VacA-secreting strains are more common among patients with distal gastric cancer than among patients with gastritis alone ${ }^{75}$. Unlike the cag island, all $H$. pylori strains possess the $v a c A$ gene $^{76}$, and expression differences between strains are due to sequence variations in $v a c A^{76}$. Regions of major sequence diversity are localized to both the vacA secretion-signal sequence (allele types sla, s1b, s1c or s2) and the mid-region (allele types $\mathrm{m} 1$ or $\mathrm{m} 2$ ) $^{7-78}$. Strains possessing the $\mathrm{m} 1$ allele are associated with enhanced gastric epithelial-cell injury ${ }^{79,80}$ and distal gastric cancer ${ }^{43,78}$ compared with vacA $\mathrm{m} 2$ strains.

A T-helper-2 response involves production of cytokines, such as IL-4, which stimulate antibody production. $\mathrm{T}_{\mathrm{H}} 2$ cytokines promote secretory immune responses of mucosal surfaces to extracellular pathogens and allergic reactions.

HYPOCHLORHYDRIA Decreased secretion of acid by the stomach, often as a result of atrophic gastritis or use of acidsuppressive medications, such as proton-pump inhibitors.
$\mathrm{Le}^{\mathrm{b}}$-expressing mice are more likely to develop severe gastritis, atrophy and anti-PARIETAL CELL antibodies (reflecting autoimmune tissue destruction) than their wild-type littermates ${ }^{82}$. BabA-expressing strains also adhere more tightly to epithelial cells, which might promote pathogenesis.

\section{Host polymorphisms and gastric cancer}

Just as certain $H$. pylori genetic elements are associated with gastric cancer, several human polymorphisms are also associated with the disease. Most of these occur within immune response genes. H. pylori induces a T-helper $\left(\mathrm{T}_{\mathrm{H}}\right) 1$-type cellular immune response in humans, whereas a closely related bacteria, Helicobacter felis, induces the same reaction in mice ${ }^{83,84}$. Experimental induction of a $\mathrm{T}_{\mathrm{H}}$-type immune response attenuates the gastritis and atrophy response that is observed in mice infected with $\mathrm{H}$. felis $^{85}$, indicating that mucosal inflammation might promote tumorigenesis.

Expression levels of the $\mathrm{T}_{\mathrm{H}} 1$ cytokine IL-1 $\beta$ are increased within the gastric mucosa of $H_{\text {. pylori }}{ }^{+}$individuals $^{86}$, and several polymorphisms have been identified in the $I L-1 \beta$ gene promoter region that affect protein expression. Individuals that are colonized by H. pylori, and that possess promoter-region polymorphisms associated with higher-than-average expression levels of IL-1 $\beta$, are at significantly increased risk of developing HYPOCHLORHYDRIA, gastric atrophy and distal gastric adenocarcinoma than individuals with polymorphisms linked to lower expression levels of IL-1 $\beta$ (REE. 87; FIG. 1; TABLE 2).

Experiments in rodent models have led to similar findings. In Mongolian gerbils infected with $H$. pylori, gastric mucosal IL-1 $\beta$ levels increase $6-12$ weeks after bacterial infection, accompanied by a reciprocal decrease in gastric-acid production ${ }^{88}$. Administration of recombinant IL-1 receptor antagonist to gerbils infected 


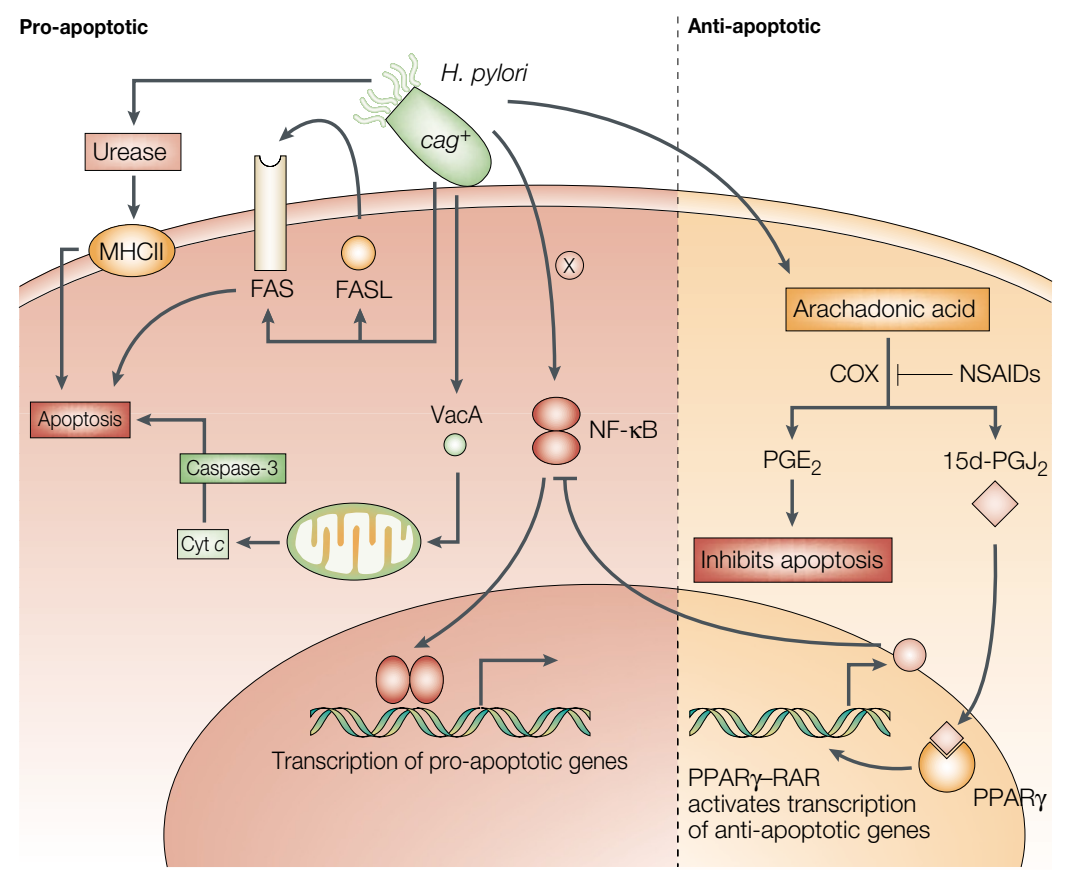

Figure $3 \mid \boldsymbol{H}$. pylori cag ${ }^{+}$strains can induce or prevent gastric epithelial-cell apoptosis. H. pylori can regulate gastric epithelial apoptosis through several mechanisms. Following adherence, signalling by the cag secretion system (but not CagA per se) leads to activation of an unknown factor(s) $X$ that leads to activation of nuclear factor-kB (NF-kB). NF-kB translocates to the nucleus to activate transcription of pro-apoptotic genes. H. pylori can also induce apoptosis by stimulating expression of FAS and its ligand (FASL). The H. pylori protein urease can induce apoptosis by binding to class II major histocompatability complex $(\mathrm{MHC})$ molecules. The $\mathrm{H}$. pylor vacA gene product causes mitochondrial release of cytochrome $c$ (cyt $c)$, which leads to activation of caspase-3 and apoptosis. H. pylori also activates pathways that downregulate apoptosis. H. pylori binding to the epithelial-cell surface generates arachadonic acid, which is metabolized to prostaglandin $E_{2}\left(P G E_{2}\right)$ and prostaglandin 15-deoxy $\Delta 12,14-J_{2}\left(15 d-P G J_{2}\right)$ by cyclooxygenase (COX) enzymes. These enzymes are inhibited by non-steroidal anti-inflammatory drugs (NSAIDs). 15d-PGJ, is an endogenous ligand of peroxisome proliferator-activated receptor(PPARy), a nuclear hormone receptor that heterodimerizes with the retinoid (RAR) family of nuclear receptors to activate transcription of target genes. These gene products inhibit NF-kB activation, however, preventing apoptosis. The COX-generated metabolite $\mathrm{PGE}_{2}$ also attenuates apoptosis. So, H. pylori has the capacity to stimulate and inhibit gastric epithelial-cell apoptosis, which might influence the risk of gastric carcinogenesis.

MAJOR HISTOCOMPATIBILITY COMPLEX

(MHC). Locus of genes that encode products essential to immune function. Class I and Class II MHC genes encode proteins that are involved in antigen presentation to $\mathrm{T}$ cells.

G-CELLS

Endocrine cells located in the gastric antrum that secrete the hormone gastrin. with $H$. pylori normalizes acid levels ${ }^{88}$, indicating that IL- $1 \beta$ is an important determinant of acid secretion within inflamed mucosa. As IL- $1 \beta$ is the most powerful inhibitor of acid secretion known, is profoundly proinflammatory, and is upregulated by $H$. pylori, this cytokine probably has a pivotal role in initiating the progression towards gastric adenocarcinoma ${ }^{89}$.

Expression of tumour necrosis factor (TNF)- $\alpha-$ another $\mathrm{T}_{\mathrm{H}} 1$ (pro-inflammatory and acid-suppressive) cytokine - is also increased within mucosa ${ }^{90}$ colonized by $H$. pylori. Polymorphisms in the gene that encode it have been associated with an increased risk of gastric cancer and its precursors ${ }^{91}$ (TABLE 2). Two different H. pylori proteins (urease B and membrane protein 1) have recently been shown to induce TNF- $\alpha$ expression and transformation in cells that constitutively overexpress the oncogenic protein RAS, indicating that enhanced genetically susceptible individuals might contribute to carcinogenesis by interacting with activating $R A S$ levels of mucosal TNF- $\alpha$ produced by $H$. pylori in mutations ${ }^{92}$. Conversely, polymorphisms that reduce expression of the anti-inflammatory cytokine IL-10 have been associated with an enhanced risk of distal gastric cancer $^{93}$ (TABLE 2).

Some studies indicate that particular MAJOR HISTOCOMPATABILITY COMPLEX (MHC) genotypes also influence gastric carcinogenesis that is induced by H. pylori. Cells that express class II MHC molecules regulate the immune response by binding antigen, processing it and presenting it to $\mathrm{CD} 4^{+} \mathrm{T}$ cells. Class II MHC molecules are expressed on gastric epithelial-cell surfaces and are upregulated in the presence of H. pylori ${ }^{94}$, indicating that the host MHC class II haplotype might partially determine the epithelialcell response to the pathogen. For example, host possession of the MHC DQA ${ }^{*} 0102$ allele was reported to increase the risk of atrophic gastritis and intestinal-type gastric adenocarcinoma associated with H. pylori $i^{95}$. Other studies have shown that inactivating mutations in $\mathrm{CDH1}$, the gene that encodes E-cadherin, are associated with familial diffuse-type gastric cancer ${ }^{96}$; however, a relationship between E-cadherin and $H$. pylori has not been established.

\section{Biological effects of $\boldsymbol{H}$. pylori}

Proliferation. What effect does $H$. pylori have on the gastric epithelium that leads to cellular transformation? One effect is interference with epithelial-cell proliferation. Coculture of $H$. pylori with epithelial cells has been shown to reduce expression of the cell-cycle regulatory protein $\mathrm{p} 27$, which leads to epithelial-cell $G_{1}$ arrest ${ }^{97,98}$. Cell-cycle arrest might be induced by DNA damage to epithelial cells. When $H$. pylori is incubated with epithelial cells, direct damage to host-cell DNA occurs through the synthesis of reactive oxygen species, as reflected by the formation of DNA adducts ${ }^{99,100}$

The host response to H. pylori can also induce epithelial-cell proliferation. These pathogens have been reported to induce hypergastrinaemia ${ }^{101}$ - the increased production of the hormone gastrin by mucosal G-CELLS. Gastrin stimulates gastric epithelial-cell proliferation in vitro by activating its receptor, CCK- $\beta^{102}$. Gastrin-deficient and gastrin-receptor-deficient mice develop altered glandular architecture ${ }^{103}$ as a result of altered epithelialcell proliferation. The ability to stimulate gastrin production might be an important aspect of tumorigenesis induced by $H$. pylori. In transgenic mice that overexpress gastrin, gastric adenocarcinomas developed in $75 \%$ of animals over 20 months old ${ }^{104}$. When these transgenic mice were infected with $H$. felis, $85 \%$ developed gastric carcinomas by eight months of age ${ }^{104}$. High gastrin levels might therefore synergize with other consequences of H. pylori colonization to promote gastric cancer.

Inflammation. $H$. pylori also activates pro-inflammatory cyclooxygenase (COX) enzymes (FIG. 3). The COX enzymes (COX-1 or COX-2) catalyse key steps in the formation of inflammatory prostaglandins ${ }^{105}$. COX-1 is expressed constitutively, whereas COX-2 is induced by cytokines such as TNF- $\alpha$, interferon (IFN)- $\gamma$, and IL-1 (REF. 105). COX-2 expression is increased in 


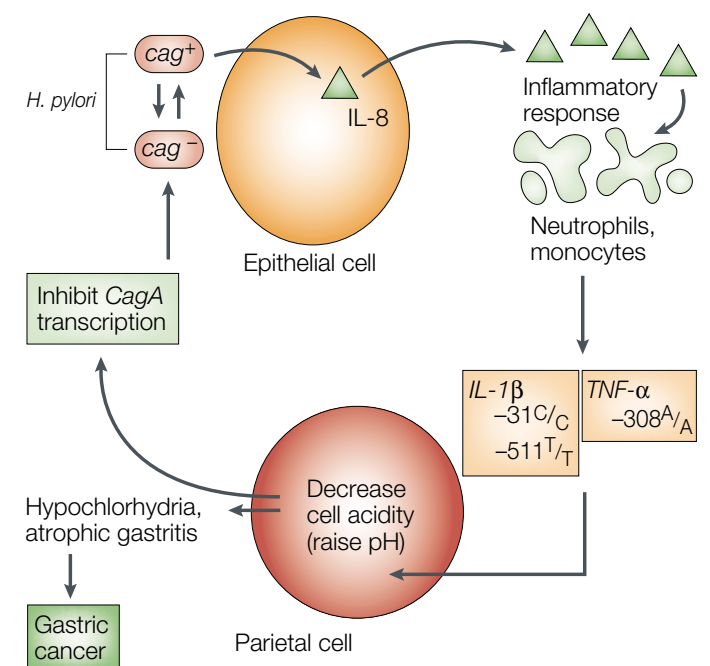

Figure 4 | Equilibrium of interactions between $\boldsymbol{H}$. pylori and its host. $H$. pylori cells signal the host and the host signals the bacterial population. $H$. pylori cag ${ }^{+}$strains promote production of the cytokine interleukin (IL)-8 by host cells, which amplifies the inflammatory response by recruiting neutrophils and monocytes. These cells release pro-inflammatory cytokines such as IL-1 $\beta$ and tumour necrosis factor (TNF)- $\alpha$, which reduce acid production by parietal cells, causing a decrease in gastric acidity and hypochlorhydria. This increases the risk of atrophic gastritis, a pre-malignant condition. By contrast, $\mathrm{cag}^{-} \mathrm{H}$. pylori strains do not induce an intense host response, and do not promote IL-8 production. The exact equilibrium between $\mathrm{cag}^{+}$and $\mathrm{cag}^{-}$cells in a population will be determined by their relative fitness under each set of local conditions. Host genotype affects this equilibrium, as individuals possessing mutations that allow for high IL-1 $\beta$ (-31 C/C allele, $-511 \mathrm{~T} / \mathrm{T}$ allele) and TNF- $\alpha$ (-308 AVA allele) expression levels have a higher gastric $\mathrm{pH}$, which downregulates cagA transcription, and provides selective pressure for $\mathrm{cag}^{-}$cells. Individuals colonized with cag bacterial cells and who express high levels of IL-1 $\beta$ and TNF- $\alpha$ are more likely to develop atrophic gastritis and consequent hypochlorhydria, which increases risk of distal gastric cancer.

epithelial cells that are co-cultured with $H$. $p y$ lori ${ }^{106}$ and within gastric mucosa of individuals infected with H. pylori ${ }^{107,108}$. COX-2 expression is further increased within pre-malignant (atrophic gastritis and intestinal metaplasia) and malignant (adenocarcinoma) lesions induced by H. pylori ${ }^{109,110}$, and COX-inhibitors such as aspirin and other non-steroidal anti-inflammatory drugs have been shown to decrease the risk of distal gastric cancer ${ }^{111,112}$. H. pylori also activates phospholipase $\mathrm{A}_{2}$, an enzyme that catalyses the formation of the prostaglandin precursor arachadonic acid, both in vitro and in vivo ${ }^{113,114}$.

The inflammatory response induced by $H$. pylori leads to the release of mutagenic substances, such as metabolites of inducible nitric oxide synthase (iNOS), which promote oncogenesis ${ }^{108,115}$. Nitric oxide, generated by iNOS, can be converted to reactive nitrogen species that modify various cellular targets, including DNA and proteins.

Superoxide anion radicals generated by neutrophils also induce DNA damage through the formation of DNA adducts $^{99}$. Serum levels of vitamin C, a scavenger of reactive oxygen species and nitrates, are inversely proportional to the prevalence of gastric cancer ${ }^{116}$. Eradication of $H$. pylori has been reported to raise gastric intraluminal ascorbic acid levels ${ }^{117}$, so the presence of $H$. pylori also affects gastric mucosal antioxidant defence mechanisms.

Apoptosis. H. pylori has been associated with both increased and reduced levels of apoptosis in the gastric epithelium, depending on the human population studied (FIG. 3). In vitro, H. pylori reproducibly stimulates gastric epithelial-cell apoptosis ${ }^{67,68,118,119}$. $H$. pylori urease, an enzyme that generates ammonia and is present within the lamina propria of colonized individuals, has been shown to bind to class II MHC molecules on the surfaces of gastric epithelial cells in vitro and induce apoptosis ${ }^{120}$. H. pylori VacA has been reported to insert into mitochondrial membranes, induce cytochrome $c$ release, and activate the caspase-3-dependent cell-death signalling cascade ${ }^{69}$.

Another mechanism by which $\mathrm{H}$. pylori can stimulate apoptosis is by inducing expression of the cell-surface receptor FAS and FAS ligand ${ }^{67,118,121,122}$ (FIG. 3). Helicobacter infection of Ifn- $\gamma$-deficient and Fas-deficient mice is associated with reduced levels of inflammation and apoptosis compared with wildtype control mice ${ }^{123-125}$. This indicates that release of $\mathrm{T}_{\mathrm{H}} 1$ cytokines induced by $H$. pylori, such as IFN- $\gamma$, might induce epithelial-cell apoptosis through a Fas-mediated pathway.

H. pylori has also been reported to induce apoptosis in gastric epithelial cells in vitro through activation of the transcription factor NF-KB ${ }^{126}$ (FIG. 3). In colonic epithelial cells, however, NF- $\mathrm{KB}$ is negatively regulated by the nuclear hormone receptor peroxisome proliferator-activated receptor- $\gamma(\text { PPAR } \gamma)^{127,128}$, and activation of PPAR $\gamma$ similarly inhibits $H$. pylori-induced activation of NF- $\mathrm{KB}$ and apoptosis in gastric cells ${ }^{126}$ (FIG. 3). Putative endogenous PPAR $\gamma$ agonist ligands include the prostaglandin 15-deoxy $\Delta 12,14-\mathrm{J}_{2}\left(15 \mathrm{~d}-\mathrm{PGJ}_{2}\right)$, a COX metabolite ${ }^{129}$. Another COX-2-generated metabolite, prostaglandin $\mathrm{E}_{2}$ $\left(\mathrm{PGE}_{2}\right)$ also inhibits apoptosis ${ }^{130}$; in contrast to proinflammatory cytokines, prostaglandins might limit the apoptotic response that develops in response to $H$. pylori.

Different $H$. pylori strains have different effects on cellular turnover, and mucosal levels of apoptosis seem to vary substantially between individuals carrying H. pylori ${ }^{67,131-133}$. Two studies showed that gastric epithelial cells from people carrying $H$. pylori cag $A^{+}$isolates have significantly higher proliferation rates, but lower apoptotic indices, than either $c a g A^{-}$or uninfected persons ${ }^{134,135}$, although a recent study reported that apoptotic indices are increased within $H$. pylori cag $A^{+}$-colonized mucosa ${ }^{136}$. How could altered levels of apoptosis increase the risk of gastric cancer? Enhanced rates of apoptosis could potentially accelerate progression to atrophic gastritis, with a concomitant increase in the risk of distal gastric adenocarcinoma. By contrast, reduced rates of cell loss, especially when accompanied by hyperproliferation, could lead to a heightened retention of mutagenized cells, which might also predispose certain colonized individuals towards development of gastric cancer. On the basis of 
the available data, it seems that apoptosis within mucosa colonized by $H$. pylori is regulated by host inflammatory mediators that modify the direct effect of the organism on epithelial cells, and the types and/or levels of mediator present (that is, $\mathrm{T}_{\mathrm{H}} 1$ cytokines versus prostaglandins) might differentially alter cancer risk.

\section{Host-bacterial equilibrium}

$H$. pylori is able to send and receive signals from the gastric epithelium, allowing host and bacteria to become linked in a dynamic equilibrium ${ }^{137}$. The equilibrium is different for each colonized individual, based on both host and bacterial characteristics ${ }^{40}$, which might explain why certain $H$. pylori strains augment the risk of carcinogenesis. For example, $\mathrm{cag}^{+}$strains induce an intense inflammatory response that involves production of IL-8. This leads to increased production of IL- $1 \beta$ and TNF- $\alpha$, which inhibit acid production (FIG. 4) - especially in hosts with polymorphisms that promote high expression levels of these factors (TABLE 2). This combination of strain and host factors results in lower gastric acidity (higher gastric $\mathrm{pH}$ ) than would occur in a person infected with a $\mathrm{cag}^{-}$strain or with polymorphisms that do not permit high expression levels of IL- $1 \beta$ or TNF- $\alpha$. However, cagA transcription is reduced as $\mathrm{pH}$ rises ${ }^{138,139}$, and the bacterial stimulus to the host diminishes, creating a negative-feedback loop that leads towards equilibrium. As $\mathrm{Cag}^{+}$and $\mathrm{cag}^{-}$strains can coexist and recombine within the same host, the percentage of $\mathrm{cag}^{+}$strains is likely to vary over time, which will affect this equilibrium (FIG. 4).

Levels of mucosal proliferation are directly related to the intensity of inflammation, that is augmented by $\mathrm{cag}^{+}$ strains. The ability of $H$. pylori in conjunction with inflammatory mediators to induce or attenuate apoptosis might also contribute to altered cellular turnover. An augmented inflammatory response induced by $\mathrm{Cag}^{+}$ strains in the gastric body, leading to decreased acid production, permits overgrowth of $\mathrm{pH}$-sensitive bacteria, conversion of ingested $\mathrm{N}$-nitrosamines to nitrites, and an increased risk of gastric cancer.

So, cancer risk is the summation of the polymorphic nature of the bacterial population in that host, the host genotype and environmental exposures (ingested nitrates), each affecting the level of the equilibrium. This deterministic model of the mucosal events related to carcinogenesis also has clinical and epidemiological ramifications. For example, people with polymorphisms associated with high levels of IL- $1 \beta$ expression and who are colonized by $\mathrm{cag}^{+}$strains might be most likely to derive benefit from $H$. pylori eradication, as such treatment could result in substantially reduced cancer risk.

\section{GERD and oesophageal adenocarcinoma}

The falling incidences of $H$. pylori carriage and gastric cancer in developed countries over the past century have been diametrically opposed by a rapidly increasing incidence of GERD and its sequelae. GERD is the strongest known risk factor for developing Barrett's oesophagus - a metaplasia of the distal oesophagus associated with an increased risk of oesophageal adenocarcinoma ${ }^{140}$. Among white males, the incidence of oesophageal adenocarcinoma has increased more than $350 \%$ since 1975 and its incidence is rising more rapidly than any other malignancy in the United States ${ }^{141}$. The relatively short (three-decade) timeframe over which the frequency of this cancer has increased indicates that an environmental factor might be involved. Could this factor be the falling incidence of $H$. pylori?

GERD is uncommon in geographical regions of the world in which most people are colonized by $\mathrm{H}$. pylori (particularly $\mathrm{cag}^{+}$strains) ${ }^{142}$. GERD and its sequelae are increasing in incidence in Western countries ${ }^{143}$, whereas the prevalence of $H$. pylori is falling ${ }^{23}$. In patients with duodenal ulcer disease (virtually always colonized with $\mathrm{cag}^{+}$strains), successful $H$. pylori eradication was associated with a doubling in the development of new-onset reflux oesophagitis over a 3-year period, compared with individuals who remained persistently colonized ${ }^{144}$. Carriage of $H$. pylori is associated with a significantly reduced risk of developing GERD, Barrett's oesophagus, and oesophageal adenocarcinoma, and the entire protective effect seems to be attributable to the presence of $\mathrm{cag}^{+}$strains ${ }^{11,12,145-150}$.

How can the ability of $\mathrm{cag}^{+}$strains to enhance the risk of distal gastric cancer be reconciled with a presumed protective effect against GERD, Barrett's oesophagus and oesophageal adenocarcinoma? The location of inflammation within the gastric niche probably contributes to this dichotomy. By inhibiting parietal-cell function (FIG. 4) and/or inducing the development of atrophic gastritis, the severe inflammation in the acidsecreting gastric body (FIG. 2) induced by cag strains (especially in patients with polymorphisms that cause increased expression levels of IL- $1 \beta$ and/or TNF- $\alpha$ ) can blunt the high-level acid secretion necessary for the development of GERD and its sequelae. Recent clinical studies have shown that severe gastritis, atrophic gastritis and reduced acid production associated with $H$. pylori colonization significantly reduce the risk of GERD ${ }^{11,151,152}$. So, the interaction of $\mathrm{cag}^{+}$strains with their hosts has opposing effects on the risk of distal cancers (increases the risk of gastric adenocarcinoma) and proximal cancers (decreases the risk of oesophageal adenocarcinoma).

\section{Conclusions}

Analytical tools now exist - including genome sequences (H. pylori and human), measurable phenotypes (CagA seropositivity), and practical animal models - to discern the fundamental biological basis of $H$. pylori-associated neoplasia, which should have direct clinical applications. For example, elucidating the role of specific proteins (CagA, VacA) secreted by H. pylori in the pathogenesis of gastric adenocarcinoma might aid in vaccine development in high-risk populations. It is important to gain more insight into the pathogenesis of gastric adenocarcinoma induced by $H$. pylori, not only to develop more effective treatments for this common cancer, but also because it might serve as a model for the role of chronic inflammation in the genesis of other malignancies, such as ulcerative colitis-associated colon cancer. 
1. Correa, P. Helicobacter pylori and gastric cancer: state of the art. Cancer Epidemiol. Biomarkers Prev 5, 477-481 the art.

2. Peterson, W. L. Helicobacter pylori and peptic ulcer disease N. Engl. J. Med. 324, 1043-1048 (1991).

3. Parsonnet, J. et al. Helicobacter pylori infection and gastric lymphoma. N. Engl. J. Med. 330, 1267-127 (1994).

4. Karnes, W. E. Jr et al. Positive serum antibody and negative tissue staining for Helicobacter pylori in subjects with atrophic body gastritis. Gastroenterology 101, 167-174 (1991).

5. Forman, D. et al. Association between infection with Helicobacter pylori and risk of gastric cancer: evidence from a prospective investigation. Br. Med. J. 302, 1302-1305 (1991)

6. Nomura, A. et al. Helicobacter pylori infection and gastric carcinoma among Japanese Americans in Hawaii. N. Engl. J. Med. 325, 1132-1136 (1991).

7. Parsonnet, J. et al. Helicobacter pylori infection and the risk of gastric carcinoma. N. Engl. J. Med. 325, 1127-113 (1991)

References 6 and 7 represent two of the origina studies that established a positive relationship between pre-existing $H$. pylori and risk of developing gastric adenocarcinoma.

8. Watanabe, Y. et al. Helicobacter pylori infection and gastric cancer. A nested case-control study in a rural area of Japan. Dig. Dis. Sci. 42, 1383-1387 (1997).

9. Sipponen, P., Kosunen, T. U., Valle, J., Riihela, M. \& Seppala, K. Helicobacter pylori infection and chronic gastritis in gastric cancer. J. Clin. Pathol. 45, 319-323 (1992).

10. Hansson, L. E. et al. Helicobacter pylori infection: independent risk indicator of gastric adenocarcinoma. Gastroenterology 105, 1098-1103 (1993).

11. Vicari, J. J. et al. The seroprevalence of cagA-positive Helicobacter pylori strains in the spectrum of gastroesophageal reflux disease. Gastroenterology 115 50-57 (1998).

This study shows that $H$. pylori cag $A^{+}$strains are reciprocally related to the prevalence of GERD and its complications, indicating that certain $\boldsymbol{H}$. pylori strains might confer a beneficial effect upon their hosts.

12. Chow, W. H. et al. An inverse relation between cag $A^{+}$strains of Helicobacter pylori infection and risk of esophageal and gastric
(1998).

13. Everhart, J. E. Recent developments in the epidemiology of Helicobacter pylori. Gastroenterol. Clin. N. Am. 29, 559-578 (2000).

14. Ernst, P. B. \& Gold, B. D. The disease spectrum of Helicobacter pylori: the immunopathogenesis of gastroduodenal ulcer and gastric cancer. Annu Rev. Microbiol. 54, 615-640 (2000).

15. Perez-Perez, G. I., Dworkin, B. M., Chodos, J. E. \& Blaser, M. J. Campylobacter pylori antibodies in humans. Ann. Intern. Med. 109, 11-17 (1988)

16. Tindberg, Y. et al. Helicobacter pylori infection in Swedish school children: lack of evidence of child-to-child transmission outside the family. Gastroenterology 121 310-316 (2001).

17. Parsonnet, J., Shmuely, H. \& Haggerty, T. Fecal and oral shedding of Helicobacter pylori from healthy infected adults. J. Am. Med. Assoc. 282, 2240-2245 (1999).

18. Sipponen, P. \& Marshall, B. J. Gastritis and gastric cancer. Western countries. Gastroenterol. Clin. N. Am. 29, 579-592 (2000)

19. Maesawa, C. et al. The sequential accumulation of genetic alterations characteristic of the colorect adenoma-carcinoma sequence does not occur between gastric adenoma and adenocarcinoma. J. Pathol. 176 249-258 (1995).

20. Uchino, S. et al. p53 mutation in gastric cancer: a genetic model for carcinogenesis is common to gastric and colorectal cancer. Int. J. Cancer 54, 759-764 (1993).

21. Hongyo, T. et al. Mutations of the K-ras and p53 genes in gastric adenocarcinomas from a high-incidence region around Florence, Italy. Cancer Res. 55, 2665-2672 (1995).

22. Blaser, M. J. Helicobacter pylori and the pathogenesis of gastroduodenal inflammation. J. Infect. Dis. 161, 626-633 (1990)

23. Parsonnet, J. The incidence of Helicobacter pylori infection Aliment. Pharmacol. Ther. 9, 45-51 (1995).

24. Howson, C. P., Hiyama, T. \& Wynder, E. L. The decline in gastric cancer: epidemiology of an unplanned triumph. Epidemiol. Rev. 8, 1-27 (1986).

25. Siman, J. H., Forsgren, A., Berglund, G. \& Floren, C. H. Association between Helicobacter pylori and gastric carcinoma in the city of Malmo, Sweden. A prospective study. Scand. J. Gastroenterol. 32, 1215-1221 (1997).
26. Hu, P. J., Mitchell, H. M., Li, Y. Y., Zhou, M. H. \& Hazell, S. L. Association of Helicobacter pylori with gastric cancer and observations on the detection of this bacterium in gastric cancer cases. Am. J. Gastroenterol. 89, 1806-1810 (1994).

27. Kikuchi, S. et al. Serum anti-Helicobacter pylori antibody and gastric carcinoma among young adults. Research Group on Prevention of Gastric Carcinoma among Young Adults. Cancer 75, 2789-2793 (1995).

28. Kokkola, A. et al. Helicobacter pylori infection in young patients with gastric carcinoma. Scand. J. Gastroenterol. 31, 643-647 (1996).

29. Barreto-Zuniga, R. et al. Significance of Helicobacter pylori infection as a risk factor in gastric cancer: serological and histological studies. J. Gastroenterol. 32 289-294 (1997).

30. Miehlke, S. et al. Histological diagnosis of Helicobacter pylor gastritis is predictive of a high risk of gastric carcinoma. Int. J. Cancer 73, 837-839 (1997).

31. Gastric cancer and Helicobacter pylori: a combined analysis of 12 case-control studies nested within prospective cohorts. Gut 49, 347-353 (2001).

32. Correa, P. et al. Chemoprevention of gastric dysplasia: randomized trial of antioxidant supplements and antiHelicobacter pylori therapy. J. Natl Cancer Inst. 92, 1881-1888 (2000)

One of the few large, randomized, controlled chemoprevention trials showing that $H$. pylori eradication increased the regression rate of premalignant lesions within the gastric mucosa.

33. Uemura, N. et al. Effect of Helicobacter pylori eradication on subsequent development of cancer after endoscopic resection of early gastric cancer. Cancer Epidemiol. resection of early gastric cancer. Cance
Biomarkers Prev, 6, 639-642 (1997)

34. Uemura, N. et al. Helicobacter pylori infection and the development of gastric cancer. N. Engl. J. Med. 345, 784-789 (2001)

35. Hirayama, F., Takagi, S., Yokoyama, Y., Iwao, E. \& Ikeda, Y. Establishment of gastric Helicobacter pylori infection in Mongolian gerbils. J. Gastroenterol. 31 (Suppl. 9), 24-28 (1996).

36. Watanabe, T., Tada, M., Nagai, H., Sasaki, S. \& Nakao, M Helicobacter pylori infection induces gastric cancer in Mongolian gerbils. Gastroenterology 115, 642-648 (1998). A seminal article reporting that $\boldsymbol{H}$. pylori colonization A seminal article reporting that $H$. pylori colonization
alone, in the absence of administration of coalone, in the absence of administration of co-
carcinogens, leads to the development of intestinaltype gastric adenocarcinoma in Mongolian gerbils. The sequence of histological lesions observed in this paper parallels the predominant histological pattern of intestinal-type gastric cancer found in humans, and so established this rodent system as a unique model of carcinogenesis induced by $\boldsymbol{H}$. pylori.

37. Honda, S. et al. Development of Helicobacter pylori-induced gastric carcinoma in Mongolian gerbils. Cancer Res. $\mathbf{5 8}$ 4255-4259 (1998)

38. Schistosomes, liver flukes and Helicobacter pylori. IARC Working Group on the Evaluation of Carcinogenic Risks to Humans. Lyon, 7-14 June 1994. IARC Monogr. Eval. Carcinog. Risks Hum. 61, 1-241 (1994).

39. Go, M. F., Kapur, V., Graham, D. Y. \& Musser, J. M. Population genetic analysis of Helicobacter pylori by multilocus enzyme electrophoresis: extensive allelic diversity and recombinational population structure. J. Bacteriol. 178, 3934-3938 (1996).

40. Blaser, M. J. \& Berg, D. E. Helicobacter pylori genetic diversity and risk of human disease. J. Clin. Invest. 107, 767-773 (2001)

41. Israel, D. A. et al. Helicobacter pylori genetic diversity within the gastric niche of a single human host. Proc. Natl Acad. Sci. USA 98, 14625-14630 (2001).

42. van Doorn, L. J. et al. Clinical relevance of the $\operatorname{cag} A$, vacA, and iceA status of Helicobacter pylori. Gastroenterology 115, 58-66 (1998).

43. Gerhard, M. et al. Clinical relevance of the Helicobacter pylori gene for blood-group antigen-binding adhesin. Proc Natl Acad Sci. USA 96, 12778-12783 (1999).

44. Tomb, J. F. et al. The complete genome sequence of the gastric pathogen Helicobacter pylori. Nature 388, 539-547 (1997).

The annotated description of the entire genome sequence from a single $H$. pylori strain. This study provided a framework for investigations into $H$. pylori-host interactions and how these affect carcinogenesis.

45. Alm, R. A. et al. Genomic-sequence comparison of two unrelated isolates of the human gastric pathogen Helicobacter pylori. Nature $\mathbf{3 9 7}, 176-180$ (1999).
The comparison of genome sequences from two unrelated $\boldsymbol{H}$. pylori strains underscored the high degree of genetic diversity that exists within this species and identified numerous strain-specific loci that might have a role in pathogenesis.

46. Odenbreit, S. et al. Translocation of Helicobacter pylori CagA into gastric epithelial cells by type IV secretion. Science $\mathbf{2 8 7}$ 1497-1500 (2000).

47. Stein, M., Rappuoli, R. \& Covacci, A. Tyrosine phosphorylation of the Helicobacter pylori CagA antigen after cag-driven host cell translocation. Proc. Natl Acad. Sc USA 97, 1263-1268 (2000).

48. Asahi, M. et al. Helicobacter pylori CagA protein can be tyrosine phosphorylated in gastric epithelial cells. J. Exp. Med. 191, 593-602 (2000).

49. Segal, E. D., Cha, J., Lo, J., Falkow, S. \& Tompkins, L. S. Altered states: involvement of phosphorylated CagA in the induction of host cellular growth changes by Helicobacter pylori. Proc. Natl Acad. Sci. USA 96, 14559-14564 (1999).

50. Cover, T. L., Dooley, C. P. \& Blaser, M. J. Characterization of and human serologic response to proteins in Helicobacter pylori broth culture supernatants with vacuolizing cytotoxin activity. Infect. Immun. 58, 603-610 (1990).

51. Crabtree, J. E. et al. Mucosal IgA recognition of Helicobacter pylori $120 \mathrm{kDa}$ protein, peptic ulceration, and gastric pathology. Lancet 338, 332-335 (1991)

52. Peek, R. M. Jr et al. Heightened inflammatory response and cytokine expression in vivo to cag $A^{+}$Helicobacter pylori strains. Lab. Invest. 73, 760-770 (1995).

53. Kuipers, E. J., Perez-Perez, G. I., Meuwissen, S. G. \& Blaser, M. J. Helicobacter pylori and atrophic gastritis: importance of the cagA status. J. Natl Cancer Inst. 87, 1777-1780 (1995).

54. Crabtree, J. E. et al. Systemic and mucosal humoral responses to Helicobacter pylori in gastric cancer. Gut $\mathbf{3 4}$, 1339-1343 (1993).

55. Blaser, M. J. et al. Infection with Helicobacter pylori strains possessing cagA is associated with an increased risk of developing adenocarcinoma of the stomach. Cancer Res. 55, 2111-2115 (1995)

56. Parsonnet, J., Friedman, G. D., Orentreich, N. \& Vogelman, H. Risk for gastric cancer in people with $\mathrm{CagA}^{+}$or $\mathrm{CagA}^{-}$ Helicobacter pylori infection. Gut 40, 297-301 (1997)

57. Sharma, S. A., Tummuru, M. K., Miller, G. G. \& Blaser, M. J. Interleukin-8 response of gastric epithelial cell lines to Helicobacter pylori stimulation in vitro. Infect. Immun. 63 1681-1687 (1995).

58. Tummuru, M. K., Sharma, S. A. \& Blaser, M. J. Helicobacter pylori pic $B$, a homologue of the Bordetella pertussis toxin secretion protein, is required for induction of IL-8 in gastric epithelial cells. Mol. Microbiol. 18, 867-876 (1995).

59. Glocker, E. et al. Proteins encoded by the cag pathogenicity island of Helicobacter pylori are required for NF-kB activation. Infect. Immun. 66, 2346-2348 (1998).

60. Sharma, S. A. Tummuru, M. K Blaser, M. J. \& Kerr, L. D. Activation of IL-8 gene expression by Helicobacter pylori is regulated by transcription factor nuclear factor- $\mathrm{K} B$ in gastric epithelial cells. J. Immunol. 160, 2401-2407 (1998).

61. Keates, S. et al. Differential activation of mitogen-activated protein kinases in AGS gastric epithelial cells by cag $^{+}$and cag- Helicobacter pylori. J. Immunol. 163, 5552-5559 (1999).

62. Naumann, M. et al. Activation of activator protein 1 and stress response kinases in epithelial cells colonized by Helicobacter pylori encoding the cag pathogenicity island. J. Biol. Chem. 274, 31655-31662 (1999).

63. Meyer-Ter-Vehn, T., Covacci, A., Kist, M. \& Pahl, H. L. Helicobacter pylori activates mitogen-activated protein kinase cascades and induces expression of the protooncogenes c-fos and c-jun. J. Biol. Chem. 275 16064-16072 (2000).

64. Yamaoka, Y., Kita, M., Kodama, T., Sawai, N. \& Imanishi, J. Helicobacter pylori cagA gene and expression of cytokine messenger RNA in gastric mucosa. Gastroenterology $\mathbf{1 1 0}$ 1744-1752 (1996).

65. Ogura, K. et al. Virulence factors of Helicobacter pylon responsible for gastric diseases in Mongolian gerbil. J. Exp. Med. 192, 1601-1610 (2000).

66. Israel, D. A. et al. Helicobacter pylori strain-specific differences in genetic content, identified by microarray, influence host inflammatory responses. J. Clin. Invest. 107 611-620 (2001).

67. Rudi, J. et al. Involvement of the CD95 (APO-1/Fas) receptor and ligand system in Helicobacter pylori-induced gastric epithelial apoptosis. J. Clin. Invest. 102, 1506-1514 (1998).

68. Peek, R. M. Jr et al. Helicobacter pylori strain-specific genotypes and modulation of the gastric epithelial cell cycle. Cancer Res. 59, 6124-6131 (1999).

69. Galmiche, A. et al. The N-terminal $34 \mathrm{kDa}$ fragment of Helicobacter pylori vacuolating cytotoxin targets 
mitochondria and induces cytochrome $c$ release. EMBO J. 19, 6361-6370 (2000).

70. Kuck, D. et al. Vacuolating cytotoxin of Helicobacter pylo induces apoptosis in the human gastric epithelial cell line AGS. Infect. Immun. 69, 5080-5087 (2001).

71. Leunk, R. D., Johnson, P. T., David, B. C., Kraft, W. G. \& Morgan, D. R. Cytotoxic activity in broth-culture filtrates of Campylobacter pylori. J. Med. Microbiol. 26, 93-99 (1988).

72. Tummuru, M. K., Cover, T. L. \& Blaser, M. J. Cloning and expression of a high-molecular-mass major antigen of Helicobacter pylori: evidence of linkage to cytotoxin production. Infect. Immun. 61, 1799-1809 (1993)

73. Covacci, A. et al. Molecular characterization of the $128-\mathrm{kDa}$ immunodominant antigen of Helicobacter pylori associated with cytotoxicity and duodenal ulcer. Proc. Natl Acad. Sci. USA 90, 5791-5795 (1993).

74. Tummuru, M. K., Cover, T. L. \& Blaser, M. J. Mutation of the cytotoxin-associated cagA gene does not affect the vacuolating cytotoxin activity of Helicobacter pylori. Infect. Immun. 62, 2609-2613 (1994).

75. Miehlke, S. et al. The Helicobacter pylori vacA s1, $\mathrm{m} 1$ genotype and cag $A$ is associated with gastric carcinoma in Germany. Int. J. Cancer 87, 322-327 (2000).

76. Atherton, J. C. et al. Mosaicism in vacuolating cytotoxin alleles of Helicobacter pylori. Association of specific vacA types with cytotoxin production and peptic ulceration. J. Biol. Chem. 270, 17771-17777 (1995). The first study to show that specific vacA alleles affect the risk of developing clinical disease in individuals infected with $\boldsymbol{H}$. pylori.

77. van Doorn, L. J. et al. Expanding allelic diversity of Helicobacter pylori vacA. J. Clin. Microbiol. 36, 2597-2603 (1998).

78. van Doorn, L. J. et al. Geographic distribution of vacA allelic types of Helicobacter pylori. Gastroenterology 116 823-830 (1999).

79. Atherton, J. C., Peek, R. M. Jr, Tham, K. T., Cover, T. L. \& Blaser, M. J. Clinical and pathological importance of heterogeneity in $v a c A$, the vacuolating cytotoxin gene of Helicobacter pylori. Gastroenterology 112, 92-99 (1997).

80. Ghiara, P. et al. Role of the Helicobacter pylori virulence factors vacuolating cytotoxin, CagA, and urease in a mouse model of disease. Infect. Immun. 63, 4154-4160 (1995).

81. Ilver, D. et al. Helicobacter pylori adhesin binding fucosylated histo-blood group antigens revealed by retagging. Science 279, 373-377 (1998)

82. Guruge, J. L. et al. Epithelial attachment alters the outcome of Helicobacter pylori infection. Proc. Natl Acad. Sci. USA 95, 3925-3930 (1998).

One of the first articles to emphasize that interactions between specific $\mathrm{H}$. pylori and host determinants influence the development of premalignant lesions within inflamed gastric mucosa

83. Mohammadi, M., Czinn, S., Redline, R. \& Nedrud, Helicobacter-specific cell-mediated immune responses display a predominant $T_{H} 1$ phenotype and promote a delayed-type hypersensitivity response in the stomachs of mice. J. Immunol. 156, 4729-4738 (1996).

84. Bamford, K. B. et al. Lymphocytes in the human gastric mucosa during Helicobacter pylori have a Thelper cell 1 phenotype. Gastroenterology 114, 482-492 (1998).

85. Fox, J. G. et al. Concurrent enteric helminth infection modulates inflammation and gastric immune responses and reduces Helicobacter-induced gastric atrophy. Nature Med. 6. 536-542 (2000)

86. Noach, L. A. et al. Mucosal tumor necrosis factor- $\alpha$ interleukin-1 $\beta$, and interleukin-8 production in patients with Helicobacter pylori infection. Scand. J. Gastroenterol. 29 425-429 (1994).

87. El-Omar, E. M. et al. Interleukin-1 polymorphisms associated with increased risk of gastric cancer. Nature $\mathbf{4 0 4}$ 398-402 (2000).

A remarkable paper showing that informative and functional host polymorphisms within the $I L-1 \beta$ gene augment the risk of gastric atrophy, hypochlorhydria and gastric cancer, but only in conjunction with and gylori colonization

88. Takashima, M., Furuta, T., Hanai, H., Sugimura, H. \& Kaneko, E. Effects of Helicobacter pylori infection on gastric acid secretion and serum gastrin levels in Mongolian gerbils. Gut 48, 765-773 (2001).

89. Beales, I. L. \& Calam, J. Interleukin-1 $\beta$ and tumour necrosis factor- $\alpha$ inhibit acid secretion in cultured rabbit parietal cells by multiple pathways. Gut 42, 227-234 (1998).

90. Crabtree, J. E., Shallcross, T. M., Heatley, R. V. \& Wyatt, J. I. Mucosal tumour necrosis factor- $\alpha$ and interleukin- 6 in patients with Helicobacter pylori associated gastritis. Gut patients with Helicobact 1473-1477 (1991)
91. El-Omar, E. M. The importance of interleukin- $1 \beta$ in Helicobacter pylori associated disease. Gut 48, 743-747 (2001).

92. Suganuma, M. et al. Helicobacter pylori membrane protein 1 a new carcinogenic factor of Helicobacter pylori. Cancer Res. 61, 6356-6359 (2001).

93. El-Omar, E. M. et al. Pro-inflammatory genotypes of IL-1 $\beta$, TNF- $\alpha$ and IL-10 increase risk of distal gastric cancer but not of cardia or oesophageal adenocarcinomas. Gastroenterology 120, A86 (2001).

94. Engstrand, L. et al. Association of Campylobacter pylori with induced expression of class II transplantation antigens on gastric epithelial cells. Infect. Immun. 57, 827-832 (1989).

95. Azuma, T. et al. The role of the HLA-DQA1 gene in resistance to atrophic gastritis and gastric adenocarcinom induced by Helicobacter pylori infection. Cancer $\mathbf{8 2}$, 1013-1018 (1998).

96. Guilford, P. et al. E-cadherin germline mutations in familial gastric cancer. Nature 392, 402-405 (1998)

97. Shirin, H. et al. Helicobacter pylori inhibits the $\mathrm{G} 1$ to $\mathrm{S}$ transition in AGS gastric epithelial cells. Cancer Res. $\mathbf{5 9}$, 2277-2281 (1999).

98. Ahmed, A. et al. Helicobacter pylori inhibits gastric cell cycle progression. Microbes Infect. 2, 1159-1169 (2000).

99. Baik, S. C. et al. Increased oxidative DNA damage in Helicobacter pylori-infected human gastric mucosa. Cancer Res. 56, 1279-1282 (1996).

100. Smoot, D. T. et al. Influence of Helicobacter pylori on reactive oxygen-induced gastric epithelial cell injury. Carcinogenesis 21, 2091-2095 (2000).

101. Levi, S. et al. Campylobacter pylori and duodenal ulcers: the gastrin link. Lancet 1, 1167-1168 (1989).

102. Hocker, M. et al. Gastrin and phorbol 12-myristate 13-acetate regulate the human histidine decarboxylase promoter through Raf-dependent activation of extracellular signal-regulated kinase-related signaling pathways in gastric cancer cells. J. Biol. Chem. 272, 27015-27024 (1997).

103. Nagata, A. et al. G protein-coupled cholecystokinin$\mathrm{B} /$ gastrin receptors are responsible for physiological cell growth of the stomach mucosa in vivo. Proc. Natl Acad. Sci. USA 93, 11825-11830 (1996).

104. Wang, T. C. et al. Synergistic interaction between hypergastrinemia and Helicobacter infection in a mouse model of gastric cancer. Gastroenterology 118, 36-47 (2000). Concomitant Helicobacter infection enhances and accelerates the development of gastric cancer in mice that overexpress gastrin, thereby delineating potential mechanisms through which transformation might occur within chronically inflamed gastric mucosa.

105. Williams, C. S., Smalley, W. \& DuBois, R. N. Aspirin use and potential mechanisms for colorectal cancer prevention J. Clin. Invest. 100, 1325-1329 (1997).

106. Romano, M. et al. Helicobacter pylori up-regulates cyclooxygenase-2 mRNA expression and prostaglandin E2 cyclooxygenase-2 mRNA expression and prostag
synthesis in MKN 28 gastric mucosal cells in vitro. synthesis in MKN 28 gastric mucosal cell

107. Sawaoka, H. et al. Helicobacter pylori infection induces cyclooxygenase-2 expression in human gastric mucosa. Prostaglandins Leukot. Essent. Fatty Acids 59, 313-316 (1998).

108. Fu, S. et al. Increased expression and cellular localization of inducible nitric oxide synthase and cyclooxygenase 2 in Helicobacter pylori gastritis. Gastroenterology 116, 1319-1329 (1999).

109. Sung, J. J. et al. Cyclooxygenase-2 expression in Helicobacter pylori-associated premalignant and malignant gastric lesions. Am. J. Pathol. 157, 729-735 (2000).

110. Ristimaki, A., Honkanen, N., Jankala, H., Sipponen, P. \& Harkonen, M. Expression of cyclooxygenase-2 in human gastric carcinoma. Cancer Res. 57, 1276-1280 (1997).

111. Farrow, D. C. et al. Use of aspirin and other nonsteroidal anti-inflammatory drugs and risk of esophageal and gastric cancer. Cancer Epidemiol. Biomarkers Prev. 7, 97-102 (1998).

112. Akre, K., Ekstrom, A. M., Signorello, L. B., Hansson, L. E. \& Nyren, O. Aspirin and risk for gastric cancer: a populationbased case-control study in Sweden. Br. J. Cancer $\mathbf{8 4}$ 965-968 (2001).

113. Pomorski, T., Meyer, T. F. \& Naumann, M. Helicobacter pylori-induced prostaglandin $\mathrm{E}(2)$ synthesis involves activation of cytosolic phospholipase A(2) in epithelial cells. J. Biol. Chem. 276, 804-810 (2001).

114. Nardone, G. et al. In vivo and in vitro studies of cytosolic phospholipase A(2) expression in Helicobacter pylori infection. Infect. Immun. 69, 5857-5863 (2001).

115. Mannick, E. E. et al. Inducible nitric oxide synthase nitrotyrosine, and apoptosis in Helicobacter pylori gastritis: effect of antibiotics and antioxidants. Cancer Res. 56 3238-3243 (1996).
116. Correa, P. et al. Review article: antioxidant micronutrients and gastric cancer. Aliment. Pharmacol. Ther. 12 (Suppl. 1) 73-82 (1998).

117. Sobala, G. M. et al. Effect of eradication of Helicobacter pylori on gastric juice ascorbic acid concentrations. Gut 34 1038-1041 (1993).

118. Wagner, S. et al. Regulation of gastric epithelial cell growth by Helicobacter pylori: evidence for a major role of apoptosis. Gastroenterology 113, 1836-1847 (1997).

119. Fan, X. et al. The effect of class II major histocompatibility complex expression on adherence of Helicobacter pylori and induction of apoptosis in gastric epithelial cells: a mechanism for T helper cell type 1-mediated damage. J. Exp. Med. 187, 1659-1669 (1998).

120. Fan, X. et al. Helicobacter pylori urease binds to class II $\mathrm{MHC}$ on gastric epithelial cells and induces their apoptosis. J. Immunol. 165, 1918-1924 (2000).

121. Jones, N. L., Day, A. S., Jennings, H. A. \& Sherman, P. M. Helicobacter pylori induces gastric epithelial cell apoptosis in association with increased Fas receptor expression. Infect. Immun. 67, 4237-4242 (1999).

122. Houghton, J., Korah, R. M., Condon, M. R. \& Kim, K. H. Apoptosis in Helicobacter pylori-associated gastric and duodenal ulcer disease is mediated via the Fas antigen pathway. Dig. Dis. Sci. 44, 465-478 (1999).

123. Sawai, N. et al. Role of $y$-interferon in Helicobacter pyloriinduced gastric inflammatory responses in a mouse model. Infect. Immun. 67, 279-285 (1999).

124. Smythies, L. E. et al. Helicobacter pylori-induced mucosal inflammation is $T_{\text {, }} 1$ mediated and exacerbated in $/ L-4$, but not IFN- $\gamma$, gene-deficient mice. J. Immunol. 165, 1022-1029 (2000).

125. Houghton, J. M. Bloch, L. M., Goldstein, M., Von Hagen, S. \& Korah, R. M. In vivo disruption of the fas pathway abrogates gastric growth alterations secondary to Helicobacter infection. J. Infect. Dis. 182, 856-864 (2000).

126. Gupta, R. A. et al. Activation of peroxisome proliferatoractivated receptor- $\gamma$ suppresses nuclear factor-kB-mediated apoptosis induced by Helicobacter pylori in gastric epithelial cells. J. Biol. Chem. 276, 31059-31066 (2001).

127. Su, C. G. et al. A novel therapy for colitis utilizing PPAR-y ligands to inhibit the epithelial inflammatory response. J. Clin. Invest. 104, 383-389 (1999).

128. Nakajima, A. et al. Endogenous PPAR- $\gamma$ mediates antiinflammatory activity in murine ischemia-reperfusion injury. Gastroenterology 120, 460-469 (2001).

129. Forman, B. M. et al. 15-Deoxy-delta 12,14-prostaglandin J2 is a ligand for the adipocyte determination factor PPAR- $\gamma$ Cell 83, 803-812 (1995).

130. Tsujii, M. \& DuBois, R. N. Alterations in cellular adhesion and apoptosis in epithelial cells overexpressing prostaglandin endoperoxide synthase 2. Cell 83, 493-501 (1995).

131. Moss, S. F., Calam, J., Agarwal, B., Wang, S. \& Holt, P. R. Induction of gastric epithelial apoptosis by Helicobacter pylori. Gut 38, 498-501 (1996).

132. Jones, N. L., Shannon, P. T., Cutz, E., Yeger, H. \& Sheman, P. M. Increase in proliferation and apoptosis of gastric epithelial cells early in the natural history of Helicobacter pylo infection. Am. J. Pathol. 151, 1695-1703 (1997).

133. Kohda, K. et al. Role of apoptosis induced by Helicobacter pylori infection in the development of duodenal ulcer. Gut 44, 456-462 (1999).

134. Peek, R. M. Jr et al. Helicobacter pylori cagA $A^{+}$strains and dissociation of gastric epithelial cell proliferation from apoptosis. J. Nat/ Cancer Inst. 89, 863-868 (1997).

135. Rokkas, T. et al. Relationship of Helicobacter pylori CagA status to gastric cell proliferation and apoptosis. Dig. Dis. Sci. 44, 487-493 (1999).

136. Moss, S. F. et al. Increased gastric epithelial cell apoptosis associated with colonization with cag $A^{+}$Helicobacter pylor strains. Cancer Res. 61, 1406-1411 (2001).

137. Kirschner, D. E. \& Blaser, M. J. The dynamics of Helicobacter pylori infection of the human stomach. J. Theor. Biol. 176, 281-290 (1995).

138. Karita, M., Tummuru, M. K., Wirth, H. P. \& Blaser, M. J. Effect of growth phase and acid shock on Helicobacter pylori cagA expression. Infect. Immun. 64, 4501-4507 pyloric
(1996).

139. Allan, E., Clayton, C. L., McLaren, A., Wallace, D. M. \& Wren, B. W. Characterization of the low-pH responses of Helicobacter pylori using genomic DNA arrays. Microbiology 147, 2285-2292 (2001)

140. Lagergren, J., Bergstrom, R., Lindgren, A. \& Nyren, O. Symptomatic gastroesophageal reflux as a risk factor for esophageal adenocarcinoma. N. Engl. J. Med. $\mathbf{3 4 0}$ 825-831 (1999).

141. Devesa, S. S., Blot, W. J. \& Fraumeni, J. F. Jr. Changing patterns in the incidence of esophageal and gastric carcinoma in the United States. Cancer 83, 2049-2053 (1998) 
142. Kang, J. Y. et al. Low frequency of endoscopic esophagitis in Asian patients. J. Clin. Gastroenterol. 16, 70-73 (1993).

143. Iftikhar, S. Y., James, P. D., Steele, R. J., Hardcastle, J. D. \& Atkinson, M. Length of Barrett's oesophagus: an important factor in the development of dysplasia and adenocarcinoma. Gut 33, 1155-1158 (1992).

144. Labenz, J. et al. Curing Helicobacter pylori infection in patients with duodenal ulcer may provoke reflux esophagitis. Gastroenterology 112, 1442-1447 (1997)

145. Werdmuller, B. F. \& Loffeld, R. J. Helicobacter pylori infection has no role in the pathogenesis of reflux esophagitis. Dig. Dis. Sci. 42, 103-105 (1997).

146. Varanasi, R. V., Fantry, G. T. \& Wilson, K. T. Decreased prevalence of Helicobacter pylori infection in gastroesophageal reflux disease. Helicobacter 3, 188-194 (1998)

147. Weston, A. P. et al. Prospective evaluation of the prevalence of gastric Helicobacter pylori infection in patients with GERD, Barrett's esophagus, Barrett's dysplasia, and Barrett's adenocarcinoma. Am. J. Gastroenterol. 95 387-394 (2000).

148. Haruma, K et al. Negative association between Helicobacter pylori infection and reflux esophagitis in older patients: case-control study in Japan. Helicobacter $\mathbf{5}$ 24-29 (2000).
149. Loffeld, R. J. et al. Colonization with cag $A^{+}$Helicobacter pylori strains inversely associated with reflux esophagitis and Barrett's esophagus. Digestion 62, 95-99 (2000).

150. Warburton-Timms, V. J. et al. The significance of $\operatorname{cag} A(+)$ Helicobacter pylori in reflux oesophagitis. Gut $\mathbf{4 9}$ 341-346 (2001)

151. El-Serag, H. B. et al. Corpus gastritis is protective against reflux oesophagitis. Gut 45, 181-185 (1999).

152. Koike, T. et al. Helicobacter pylori infection prevents erosive reflux oesophagitis by decreasing gastric acid secretion. Gut 49, 330-334 (2001).

Acknowledgements

Supported in part by the National Institutes of Health, by the Medica Research Service of the Department of Veterans Affairs, and by the Foundation for Digestive Health and Nutrition Fiterman Award.

\section{(2) Online links}

Databases

The following terms in this article are linked online to:

CancerNet: http://cancernet.nci.nih.gov/

gastric adenocarcinoma | non-Hodgkin's lymphoma

oesophageal adenocarcinoma

LocusLink: http://www.ncbi.nlm.nih.gov/LocusLink caspase-3 | CCK- $\beta$ | CDH1 | COX-1 | COX-2 | cytochrome c | E-cadherin | gastrin | gastrin receptor | IFN- $\gamma$ | LL-1 | IL-1 1 | |L-8 | IL-10 | iNOS | NF-kB | p27 | phospholipase A2 | PPARy | RAS TNF- $\alpha \mid$ TP53

Medscape DrugInfo:

http://promini.medscape.com/drugdb/search.asp

aspirin

\section{FURTHER INFORMATION}

AstraZeneca's Gastroesophageal Reflux Disease (GERD)

information resource centre: http://www.gerd.com/

GERD online: $\mathrm{http}: / /$ gerdonline.itgo.com/index.html

Medline Plus web site on oespophageal cancer:

Medline Plus web site on oespophageal cancer:
http://www.nlm.nih.gov/medlineplus/esophagealcancer.html

http://www.nlm.nih.gov/medlineplus/eso

http://www. oncolink.com/templates/types/article.cfm?c=5\&s=14 \&ss $=105 \&$ id $=1736$

Oncology Forum's web site on oesophageal cancer: http://www.oncologychannel.com/esophagealcancer/

The Canadian H. pylori web site:

http://www.canadianhp.com/english/gastric_cancer.html The US Centers for Disease Contol's factsheet on H. pylori and peptic ulcer disease: http://www.cdc.gov/ulcer/md.htm University of Utah Gastrointestinal Pathology Index: http://medlib.med utah.edu/WebPath/GIHTML/GIIDX_htm

Access to this interactive links box is free online. 